\title{
Immunogeneity and structural organisation of some pLCR-encoded proteins of Yersinia pestis
}

\author{
V. A. FEODOROVA and Z. L. DEVDARIANI \\ Laboratory of Hybridomas, Russia State Antiplague Research Institute 'Microbe', Saratov, Russia
}

\begin{abstract}
A novel method of cultivation of Yersinia pestis EV-76 and its isogenic strains KM-217 $\left(\mathrm{pPst}^{-} ; \mathrm{pCad}^{+} ; \mathrm{pFra}^{-}\right)$and $\mathrm{KM}-218\left(\mathrm{pPst}^{-} ; \mathrm{pCad}^{-} ; \mathrm{pFra}^{-}\right)$and careful extraction of $Y$. pestis proteins (YPPs) permitted isolation of $>35$ low $\mathrm{Ca}^{2+}$ response plasmid (pLCR)encoded products, some of which are potentially new members of the LCR family. Immunisation with each YPP demonstrated that 25-, 54-, 72- and 87-kDa YPPs provided the highest level of protection in mice challenged with $Y$. pestis virulent strain 231 . Their immunological relationship was established with monoclonal antibodies (MAbs) and revealed several common properties, including oligosaccharide binding with specificity for N-acetylglucosamine. Affinity chromatography with MAb to the 25-kDa YPP permitted purification of the relevant antigen and its precursor. Their existence in the form of a complicated protein molecule was shown.
\end{abstract}

\section{Introduction}

Yersinia pestis harbours a 40-50 MDa plasmid (pLCR) which is necessary for virulence in all three yersiniae pathogenic for man [1]. This plasmid is associated with a complex virulence property of yersiniae, called the low $\mathrm{Ca}^{2+}$ response (LCR), i.e., $\mathrm{Ca}^{2+}$-independent growth at $37^{\circ} \mathrm{C}$, auto-agglutination, serum resistance, tissue culture cell adherence and cytotoxicity, production of $\mathrm{V}$ antigen (now called LcrV) and a set of specific outer-membrane proteins (Yops) [2-6]. The maximal expression of pLCR-encoded products is observed at $37^{\circ} \mathrm{C}$ in the absence of $\mathrm{Ca}^{2+}$, as millimolar concentrations of calcium in the medium down-regulate LCR and secretion of the proteins is blocked [7,8].

Yops prevent phagocytosis, poison phagocytic cells, moderate the inflammatory response by sequestering thrombin and delay development of a cell-mediated immune response by subverting signal transduction and inhibiting cytokine synthesis [9-13].

At least 25 Yops are known [1, 2, 5-7, 14]. However, when sequencing pLCR of $Y$. pestis KIM5 (pCD1) a set of potentially new members of the LCR virulence system with unknown functions was identified [15].

Received 21 Oct. 1999; revised version accepted 27 March 2000.

Corresponding author: Dr V. A. Feodorova

(e-mail: postmaster@microbe.saratov.su).
This indicated the necessity for further investigations of pLCR-products, their molecular targets, immunochemical structure and role in $Y$. pestis virulence and protection against plague infection.

\section{Materials and methods}

\section{Bacterial strains and culture conditions}

The characteristics of $Y$. pestis EV-76 and its isogenic strains are listed in Table 1.

The strains were grown in an apparatus constructed by Shesterenko (ACM-Sh) [18]. The bacteria were grown on $60 \mathrm{~L}$ Hottinger agar, $\mathrm{pH} 7.2$, containing $\mathrm{MgSO}_{4}$ $80 \mathrm{mg} / \mathrm{L}$ for $24 \mathrm{~h}$ at $28^{\circ} \mathrm{C}$. Then $60 \mathrm{~L}$ Hottinger broth, pH 7.2, containing $\mathrm{MgSO}_{4} 2.4 \mathrm{~g} / \mathrm{L}$ and galactose $0.1 \%$ were added and cultivation was continued for $24 \mathrm{~h}$ at $37^{\circ} \mathrm{C}$. For studying the immunogenic properties of $Y$. pestis proteins (YPPs) in protection experiments, $Y$. pestis virulent strain 231 was grown on Hottinger agar (pH 7.2-7.4) and incubated at $28^{\circ} \mathrm{C}$ for $48 \mathrm{~h}$.

Table 1. Y. pestis EV-76 and its isogenic strains used in this study

\begin{tabular}{llc}
\hline Strain & Plasmid profile & Reference \\
\hline EV-76 & pPst $^{+} ; \mathrm{pLCR}^{+} ; \mathrm{pFra}^{+}$ & 17 \\
$\mathrm{KM}-217$ & $\mathrm{pPst}^{-} ; \mathrm{pLCR}^{+} ; \mathrm{pFra}^{-}$ & 16 \\
$\mathrm{KM}-218$ & $\mathrm{pPst}^{-} ; \mathrm{pLCR}^{-} ; \mathrm{pFra}^{-}$ & 16 \\
\hline
\end{tabular}




\section{Isolation of YPPS}

YPPs were isolated from $Y$. pestis strains KM-217, KM-218 and EV-76 cultivated in ACM-Sh. The bacterial cells sedimented spontaneously and antigens were extracted twice from the cells with $\mathrm{NaCl} 2.5 \%$ containing toluene $0.2 \%$ and were precipitated at an iso-electric point of $\mathrm{pH} 4.2$ in the presence of sodium hexametaphosphate. The preparation was purified on Sephacryl S-300 (Pharmacia) and by ion-exchange chromatography on a DE-52 anion exchanger. For immunisation and ELISA, YPPs were separated by SDS-PAGE on polyacrylamide $12.5 \%$ gels according to Laemmli [19]. After staining the gels with Coomassie Brilliant Blue R $250 \quad 0.2 \%$, separated proteins bands were cut out and homogenised in phosphate-buffered saline (PBS) to a protein concentration of $2-4 \mu \mathrm{g} / \mathrm{ml}$.

\section{Isolation of outer-membrane proteins (OMPs)}

OMPs isolated from $Y$. pestis EV-76 grown on Hottinger agar at $28^{\circ} \mathrm{C}$ for $48 \mathrm{~h}$ in ACM-Sh by the method of Osborn et al. [20] were a kind gift from Dr A. A. Scherbakov.

\section{Animal immunisation and bacterial challenge}

Groups of female, 8-10-week-old outbred mice were immunised three times intraperitoneally with $0.5 \mathrm{ml}$ of each YPP with 14-day intervals between the inoculations. Unimmunised mice served as controls. At 3 days after the last immunisation, all mice were given 100 $\mathrm{LD}_{50}$ of virulent $Y$. pestis strain $231\left(\mathrm{LD}_{50}=6 \mathrm{cfu}\right)$ by subcutaneous injection. The efficiency of immunisation was estimated from the number of surviving mice. The infected mice were monitored daily for 21 days. The surviving mice were then bled and killed and their spleens were examined for viable $Y$. pestis infection.

\section{Antiserum monospecificity}

Antiserum monospecificity was studied by immunodiffusion in gels according to Ouchterlony [21] with YPPs from $Y$. pestis KM-217 and mouse antisera against each YPP.

\section{Measurement of serum antibody titre}

Mice were anaesthetised as described previously [22]. Blood was obtained from the tail vein of each mouse on day 3 after immunisation, 1 day before $Y$. pestis challenge. Total immunoglobulin G (IgG) serum antibody titres to each of the antigens were determined by two ELISA modifications.

Indirect ELISA. ELISA plates (96-well) were sensitised with the YPPs $(100 \mu \mathrm{l} /$ well $)$ at $10 \mu \mathrm{l}$ of protein $/ \mathrm{ml}$ and were incubated overnight at $4^{\circ} \mathrm{C}$. The wells were washed three times with a washing buffer (PBS containing Tween-20 0.05\%) and saturated with bovine serum albumin (BSA) $1 \%$ in PBS for $1 \mathrm{~h}$ at $37^{\circ} \mathrm{C}$ and washed as above. Then, two-fold serial dilutions of the mouse sera from 1 in 40 to 12 in $10^{6}$ were applied in triplicate and the plates were reincubated for $1 \mathrm{~h}$ at $37^{\circ} \mathrm{C}$. After washing, a 1 in 1000 dilution of peroxidase-labelled rabbit antimouse $\mathrm{IgG}$ (Sigma) was used as a conjugate. The plates were incubated for $1 \mathrm{~h}$ at $37^{\circ} \mathrm{C}$. The wells were washed six times and the substrate solution containing 2,2'-azinobis(3-ethylbenzthiazoline sulphonic acid) $22.3 \mu \mathrm{g} / \mathrm{ml}, \mathrm{H}_{2} \mathrm{O}_{2} 0.0003 \%$ in citrate buffer $(0.05 \mathrm{M}$, $\mathrm{pH}$ 4.4) was added (100 $\mu \mathrm{l} /$ well). The plates were incubated for $30 \mathrm{~min}$ at room temperature and the optical density at $405 \mathrm{~nm}$ was measured with a multichannel ELISA plate reader.

Indirect double antibody sandwich ELISA. ELISA plates (96-well) were sensitised with rabbit IgG against YPPs $(100 \mu \mathrm{l} /$ well $)$ at a protein concentration of $10 \mu \mathrm{g} / \mathrm{ml}$. SDS-PAGE-extracted YPPS at $1-2 \mu \mathrm{g} / \mathrm{ml}$ were used as antigens. After incubation for $1 \mathrm{~h}$ at $37^{\circ} \mathrm{C}$ and washing, two-fold serial dilutions of mouse sera from 1 in 40 to 1 in $10^{6}$ were added. The remaining procedures were performed as described above. The endpoint titre was defined as the highest test serum dilution giving a reading of $0.4 \mathrm{OD}$ units after subtracting the background from the wells without antigen. The results obtained were expressed as the geometric mean titre (GMT) or $\log _{10}$ mean and SD endpoint titres.

\section{$S D S-P A G E$}

YPPs and affinity-purified antigens 1 and 2 together with low-mol.-wt markers (Sigma) were subjected to SDS-PAGE according to Laemmli [19]. A 4\% stacking gels and $12.5 \%$ or $10 \%$ separating gel were used respectively. Electrophoresis was performed at a constant current of $35 \mathrm{~mA}$ in Tris-glycine buffer ( $\mathrm{pH} 8.3$ ) containing SDS $0.1 \%$ for $2.5 \mathrm{~h}$. Gels were stained with Coomassie Brilliant Blue R 250 (Sigma) $0.2 \% \mathrm{w} / \mathrm{v}$ in ethanol $25 \% \mathrm{v} / \mathrm{v}$-acetic acid $7 \% \mathrm{v} / \mathrm{v}$.

\section{Preparation of anti-Id-Ab}

Murine BALB/c monoclonal antibodies (MAbs) (IgG1) against YPPs 2, 8, 19, 21 secreted by the Y.p. $2 \mathrm{~A}_{10} 3 \mathrm{~F}_{8} \mathrm{~B}_{2}$. Sp., Y.p. $2 \mathrm{~A}_{10} 3 \mathrm{~F}_{8} \mathrm{G}_{4}$.Sp., Y.p. $2 \mathrm{~A}_{7} 2 \mathrm{D}_{8} \mathrm{E}_{5}$. Sp and Y.p. $3 \mathrm{~A}_{10} 3 \mathrm{~B}_{6}$.Sp. hybridomas, respectively, were used to induce anti-Id-Ab. $F_{(a b) 2}$-fragments of these MAbs were prepared according to Ishikawa et al. [23]. $\mathrm{BALB} / \mathrm{c}$ mice received four intraperitoneal injections of $25-50 \mu \mathrm{g}$ of $\mathrm{F}_{(\mathrm{ab}) 2}$-fragments at 14-day intervals. Three days after the last injection, mice were infected with $2 \times 10^{6} \mathrm{Sp} 2 / 0$-Ag.14. myeloma cells. Immunoglobulins were concentrated from the ascitic fluids with $45 \%$ saturated ammonium sulphate solution and purified through Sephadex G-50 (Pharmacia). 


\section{Haemagglutination (lectin) assay}

Haemagglutination assays were performed in 96-well round-bottomed microtitration plates in a final volume of $0.2 \mathrm{ml}$. Normal sheep erythrocytes (SRBC) and human erythrocytes (HRBC) were collected in the presence of heparin, washed three times in PBS and resuspended to a final concentration of $1.5 \%$ in PBS. Antigen 1 and each anti-Id-Ab were resuspended in PBS, serially diluted in the same buffer at a dilution ratio of 1 in 2 in test plates, and then mixed with an equal volume of SRBC or HRBC. Normal mouse IgG and PBS were used as negative controls. The plates were incubated at room temperature for $2 \mathrm{~h}$. Haemagglutination titres were expressed as the highest anti-Id$\mathrm{Ab}$ dilution that gave strong visible haemagglutination (see Results). The ability of different sugars to inhibit agglutination was tested as described previously [24] by mixing $5 \mu \mathrm{l}$ of each sample with $5 \mu \mathrm{l}$ of the sugar solutions $(1 \mathrm{mg} / \mathrm{ml})$ (glucose, mannose, galactose, Nacetyl-D-galactosamine, $\mathrm{N}$-acetylglucosamine or L-fucose), before the addition of $100 \mu \mathrm{l}$ of the SRBC and HRBC. Haemagglutination was monitored visually. Titres were expressed as above.

\section{Slide agglutination assay}

$Y$. pestis $\mathrm{EV}-76$ was grown for $48 \mathrm{~h}$ at $37^{\circ} \mathrm{C}$ on Hottinger agar ( $\mathrm{pH} 7.2-7.4)$ and resuspended in PBS to $1 \times 10^{9}$ cells/ml. MAbs against YPPs 2, 8, 19, and 21 were diluted 1 in 100 in PBS and mixed on microscope slides at room temperature with an equal volume $(15 \mu \mathrm{l})$ of bacterial suspension. A $4+$ reaction was scored if there was immediate clumping upon rotation of the slide. A score of zero was given if there was no visible clumping after gentle agitation at room temperature for $2 \mathrm{~min}$. Intermediate reactions were given a score of 3-1 as appropriate.

\section{Purification of antigens}

Ascitic fluid from $\mathrm{BALB} / \mathrm{c}$ mice infected with hybridoma Y.p. $2 \mathrm{~A}_{7} 2 \mathrm{D}_{8} \mathrm{E}_{5}$.Sp. producing MAb to YPP 19 was filtered, centifuged and precipitated twice with ammonium sulphate at $40-45 \%$ saturation. The precipitate was redissolved in $0.14 \mathrm{M}$ PBS ( $\mathrm{pH}$ 8.3) and the antibody was purified by affinity chromatography on a protein A-Sepharose 4B column. The two forms of YPP 19 (antigens 1 and 2) from solubilised YPPs preparation (for the purification of antigen 1) and OMPs [20] (for the purification of antigen 2) were purified by affinity chromatography with a MAb to YPP 19-Sepharose 4B column. After extensive washing of the column, the bound protein was eluted with $100 \mathrm{mM}$ citric acid ( $\mathrm{pH} \mathrm{3.0)}$; the eluate was immediately neutralised and dialysed against PBS ( $\mathrm{pH}$ 7.2). The purified protein antigens 1 and 2 were concentrated with PEG 35000 (Sigma) and separated by SDSPAGE $10 \%$ as described above.

\section{Preparation of hybridomas producing MAbs}

MAbs to YPPs 2, 8, 19, and 21 were prepared by the hybridoma technique. Briefly, female BALB/c mice, each 6-10 weeks old and weighing 18-20 g, were given three intraperitoneal doses of YPPs at 2-week intervals according to the following schedule. The first injection contained $25 \mu \mathrm{g}$ of YPPs emulsified in complete Freund's adjuvant (Sigma); the remaining injections contained $50 \mu \mathrm{g}$ of the antigen. The sensitised spleen cells were fused with a mouse myeloma cell line (Sp2/O-Ag.14) according to Galfre et al. [25]. Hybridoma cells were cloned by the method of limited dilution. MAbs produced by the hybridomas were screened by an indirect immunofluorescence test (IIFT). The class of all MAbs was determined by immunodiffusion [21] and found to be IgG1.

\section{Indirect immunofluorescence test (IIFT)}

To select MAbs, IIFT was used both for initial screening and also after cloning of hybridomas. Slide smears were prepared from a suspension of live cells $\left(1 \times 10^{7-8} / \mathrm{ml}\right)$ of $Y$. pestis $\mathrm{KM}-217$ for initial screening and of three $Y$. pestis strains with different plasmid profiles (EV-76, KM-217, KM-218) for testing after cloning. All the smears were air-dried and fixed with ethanol $96 \%$ for $30 \mathrm{~min}$. The smears were stained with FITC-labelled rabbit anti-mouse immunoglobulins for $20 \mathrm{~min}$, washed in PBS ( $\mathrm{pH} 7.2$ ) and air-dried. The intensity of immunofluorescence was estimated visually by fluorescence microscopy (ML-2; Lomo, Russia). RMPI-1640 medium (Flow Laboratories, Irvine) and the culture supernate of myeloma cells maintained in RPMI-1640 medium were used as negative controls.

\section{Establishment of serological relationship of YPPs $2,8,19$ and 21}

Indirect dot-ELISA was used to establish the immunological relationship of antigens 1 and 2 and the MAbs against YPPs 2, 8, 19 and 21. Briefly, antigens 1 and 2 at $1 \mathrm{mg} / \mathrm{ml}$ were dotted on to a nitrocellulose membrane (Schleicher-Schuell, pore size $22 \mu \mathrm{m}$ ) and fixed with ethanol $96 \%$ for $20 \mathrm{~min}$. The membrane was then washed three times in PBS and blocked with skim milk $3 \%$ for $15 \mathrm{~min}$ at $37^{\circ} \mathrm{C}$. MAbs at a protein concentration of $1 \mathrm{mg} / \mathrm{ml}$ were dotted over the antigens and the membrane was incubated for $15 \mathrm{~min}$. Peroxidase-labelled rabbit anti-mouse immunoglobulin $G$ antibodies (Sigma) were diluted to 1 in 2000 in the same buffer. The peroxidase activity was revealed after incubation for 2-3 min at room temperature with 3,3diaminobenzidine (Sigma) $0.05 \%$ in PBS (pH 7.4) and $\mathrm{H}_{2} \mathrm{O}_{2} \quad 0.03 \%$.

\section{Adjuvant activity of antigen 2}

Female BALB/c mice $8-10$-weeks old, $(\mathrm{n}=40)$ were used to study the adjuvant properties of antigen 2 . The 
mice were divided into four groups each of 10 mice and immunised three times with $2 \times 10^{7}$ sodium merthiolate-treated cells of $Y$. pseudotuberculosis II, Y. pseudotuberculosis V, Y. pseudotuberculosis II mixed with $10 \mu \mathrm{g}$ of antigen 2 and Y. pseudotuberculosis V mixed with $10 \mu \mathrm{g}$ of antigen 2 at 2-week intervals. At 3 days after the last immunisation, specific antibody titres were measured by standard indirect ELISA with $1 \times 10^{9}$ cfu of $Y$. pseudotuberculosis II and $\mathrm{V}$ to coat each well of 96-well flat-bottomed microtitration plates.

\section{Statistics}

Student's $t$ test, analysis of variance and least significant difference tests were used to compare the antibody responses of the mouse sera tested and to determine the mean time of death of the infected animals. A difference with a $\mathrm{p}$ value of $\geqslant 0.05$ was considered insignificant.

\section{Results}

\section{SDS-PAGE of YPPS}

At present, some 25 proteins of $Y$. pestis have been described [1] and designated Yops [2,5-7]. In this study more protein products of an LCR plasmid were defined. They were called YPPs as it was sometimes difficult to relate them precisely to any of the Yops described previously.

Fig. 1 shows the profiles of the YPPs isolated from $Y$. pestis strains KM-217 (YPPs-KM-217), KM-218 (YPPs-KM-218) and EV-76 (YPPs-EV-76). More proteins (c. 40) were found in KM-217 than KM-218. Both of them possessed several common YPPs of which six basic ones $(5,6,7,26,31,39)$ were studied. Some of the YPPs defined in KM-217 were also identified in EV-76. Thus, these proteins were plasmidencoded polypeptides. Some proteins $(1,9,10,11,12$, $16,29,30,38)$ appeared in $\mathrm{KM}-217$ as minor bands, whereas in EV-76 the same proteins were seen as major bands. YPPs 1, 2, 8-12, 14, 16, 18-21, 23, 25, 27-30, 35,38 and 39 appeared to be resistant to degradation by the pla protease, as they were identified in both KM-217 and EV-76. YPPs 3-7, 13, 15, 17, 22, 24, 26, $31-34,36,37$ and 40 were absent in YPPs-EV-76, being completely degraded by the pla protease [26]. YPPs 1 and 19, seen in only YPPs-KM-217, were separated from proteins with similar mol.wt seen in both YPPs-KM-217 and YPPs-KM-218 by two-dimensional electrophoresis (data not shown).

Interestingly, although both YPPs-KM-217 and YPPsEV-76 contained proteins 18 and 19, in the latter an additional 26-kDa protein (18a) was seen between proteins 18 and 19. Furthermore, in YPPs-EV-76, three

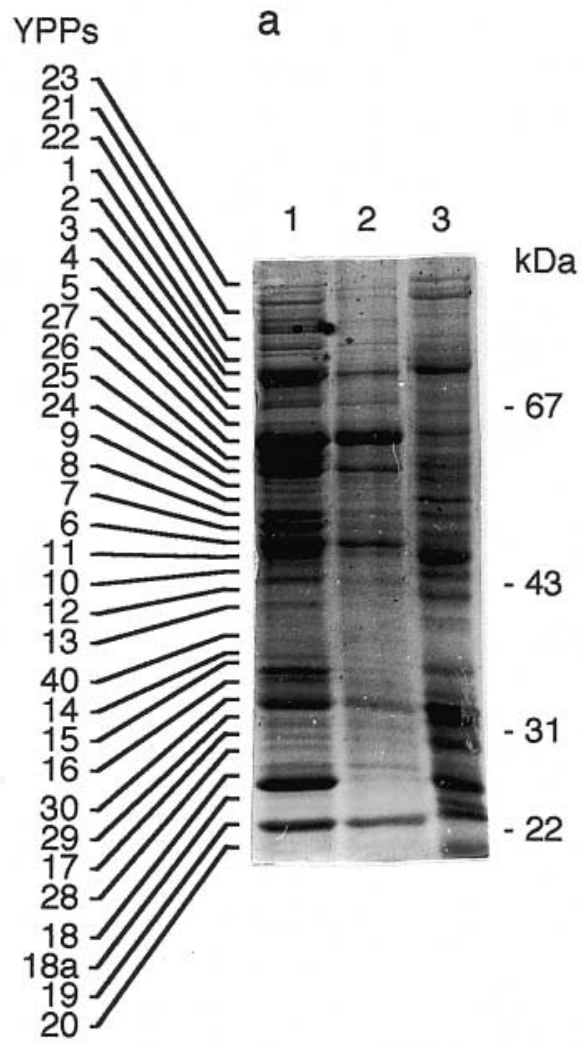

\section{b}

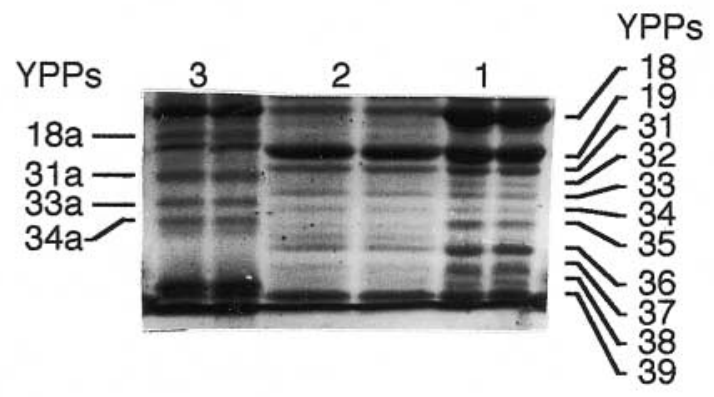

Fig 1. SDS-PAGE of YPPs preparations of Y. pestis KM-217 (lane 1), KM-218 (2) and EV-76 (3) on acrylamide $12.5 \%$ gel (a) and acrylamide $15 \%$ gel (b). The molecular masses of markers are indicated on the right; the positions of YPPs are indicated on the left. 
proteins of $23-24 \mathrm{kDa}, 26 \mathrm{kDa}$ and $22.2 \mathrm{kDA}$, which were present in YPPs-KM-217 but absent in YPPs-EV76 (Fig. 1b), were found between proteins 31 and 32 (31a), 33 and 34 (33a), 34 and 35 (34a), respectively.

\section{Antibody titres}

The geometric mean YPPs antibody titres as determined by ELISA for pooled serum samples from each mouse group are presented in Fig. 2. The immune sera of all the mice immunised with each of the YPPs were shown to react specifically with both YPP preparations and each of the relevant peptides isolated from YPP preparations by SDS-PAGE followed by electro-elution. The highest antibody titre, 1 in 128000 , was registered in YPP 19-immunised mice. The lowest antibody titres were detected in mice immunised with YPP 6 and YPP 13. The remaining proteins induced antibody formation to titres of $4000-64000$. The pooled serum samples from each group of mice produced one single well defined precipitin line with YPPs-KM-217 by gel immunodiffusion (data not shown).

\section{Survival of animals}

As indicated in Table 2, most survivors were found in mice immunised with YPP 2 and YPP 19, 50\% and $58 \%$, respectively. Immunisation with YPP 8 and YPP 21 also provided a high level of protection $-36.4 \%$ survival in both cases. No protection was observed in mice immunised with YPPs 3, 4, 11, 20, 23, 31-39. The mean times to death of the immunised and nonimmunised animals are shown in Table 2.

In mice immunised with YPP 19, the highest level of protection correlated with the highest specific antibody titre to the relevant protein. Immunisation with YPPs 2, 8 and 21 also provided a rather high level of protection and specific antibody titres (Fig. 2 and Table 2). Deaths of mice before 21 days were associated with Y. pestis infection, as all of them had positive spleen cultures. At the same time, all mice that survived had negative $Y$. pestis spleen cultures.

\section{Affinity chromatography}

Antigen 1 was purified from YPP preparations by affinity chromatography on a Sepharose 4B column with MAbs to YPP19. On SDS-PAGE, the purified antigen was resolved into five protein bands (three major and two minor) corresponding to its subunits (Fig. 3, lane 2). Based on mass comparisons, proteins of 25, 54 and $87 \mathrm{kDa}$ were identified as YPPs 19, 8 and 21 , respectively, and proteins of 22 and $125 \mathrm{kDa}$ were designated YPP 41 (because no reaction with Mab to YPP 35 was observed) and YPP 42, respectively. YPP 42 was possibly one of the proteins included in a complex of minor proteins designated YPP 23 (Table 2 ). To study further antigen 1, the role of disulphide bonds in its conformation was investigated. When 2mercaptoethanol was omitted from the denaturing buffer, the same-sized proteins except YPP 21 were observed (Fig. 3, lane 1). All five proteins were revealed in YPPs-KM-217 and YPPs-EV-76 isolated from the micro-organisms cultivated in growth conditions optimal for Yops synthesis [16, 18, 27] (Fig. 1, lanes 1 and 3). None of these proteins was found in $Y$. pestis strain KM-218 lacking the pLCR (pCad) cultivated at $37^{\circ} \mathrm{C}$ and $Y$. pestis EV-76 cultivated at $28^{\circ} \mathrm{C}$ on Hottinger agar (Fig. 3, lane 3).

Antigen 2 purified from OMPs was shown on SDSPAGE under reducing conditions to consist of two proteins of 33 and $43 \mathrm{kDa}$, but without 2-mercaptoethanol only a $22-\mathrm{kDa}$ protein was seen.

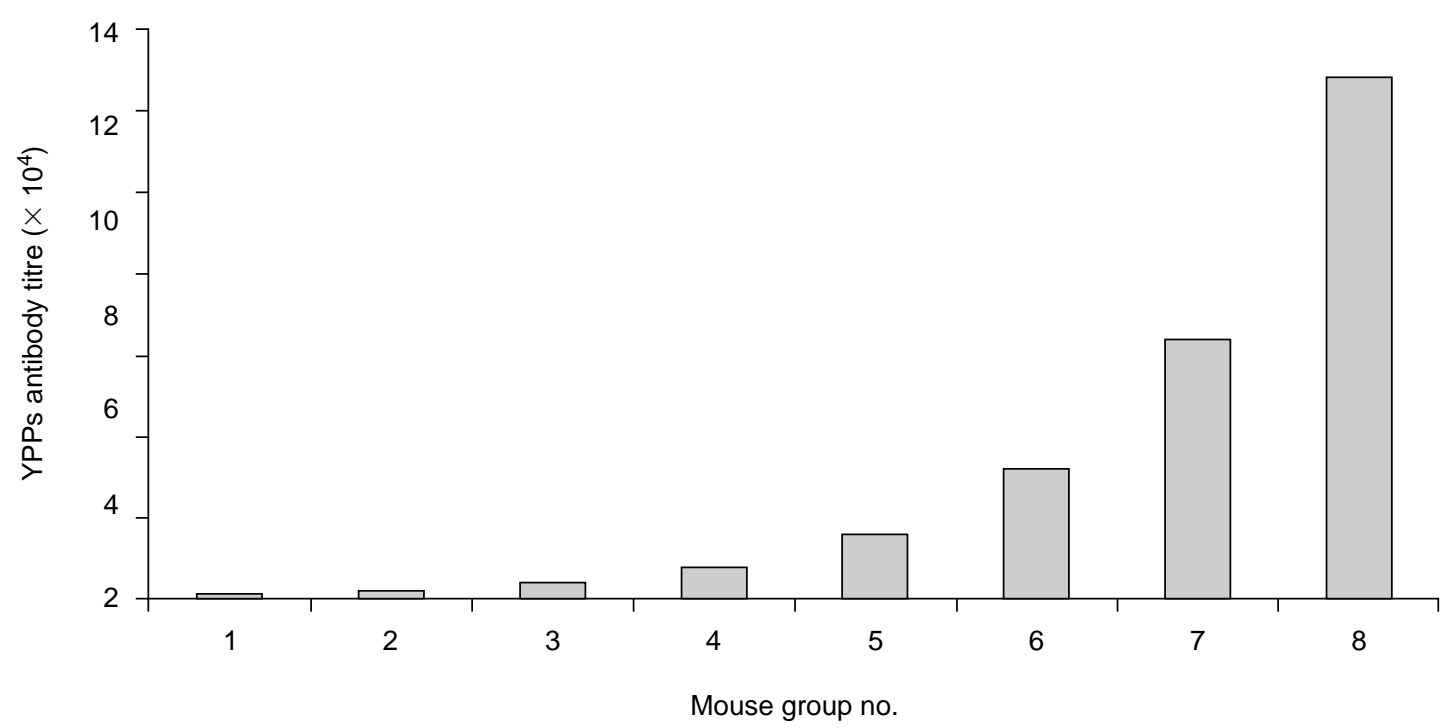

Fig 2. Geometric mean antibody titres of pooled serum samples from mouse groups immunised with each component of YPPs-KM-217: 1, YPPs 34, 37, 38; 2, YPPs 6, 13, 31, 33, 35, 36, 39 and 40; 3, YPPs 7, 8, 9, 14, 15, 20, 21, 22, 23, $24,25,26,27,32 ; 4$, YPP 11; 5, YPPs 17, 18, 28, 29, 30; 6, YPPs 1, 2, 3, 4, 16; 7, YPPs 5, 10, $12 ; 8$, YPP 19. 
Table 2. Characteristics of proteins isolated from Y. pestis KM-217

\begin{tabular}{|c|c|c|c|c|c|c|c|}
\hline \multirow[b]{2}{*}{ Protein } & \multirow{2}{*}{$\begin{array}{l}\text { Mol.wt } \\
(\mathrm{kDa})\end{array}$} & \multicolumn{3}{|c|}{$\begin{array}{l}\text { Presence in electrophoretic profiles of } \\
\text { YPPs preparation of } Y \text {. pestis strain }\end{array}$} & \multirow{2}{*}{$\begin{array}{l}\text { Degradation } \\
\text { by pla } \\
\text { protease }\end{array}$} & \multirow{2}{*}{$\begin{array}{l}\text { Percentage of } \\
\text { survivors }(\%)\end{array}$} & \multirow{2}{*}{$\begin{array}{l}\text { Mean (SD) } \\
\text { time to } \\
\text { death (days) }\end{array}$} \\
\hline & & KM-217 & KM-218 & EV-76 & & & \\
\hline 1 & 74 & + & - & + & - & 12.5 & $7.1(1.0)$ \\
\hline 2 & 72 & + & - & + & - & 50.0 & $7.0(0.6)$ \\
\hline 3 & 70 & + & - & - & + & 0 & $7.0(0.5)$ \\
\hline 4 & 68 & + & - & - & + & 0 & $5.4(0.3)$ \\
\hline 5 & 63 & + & + & - & + & 25 & $6.3(0.4)$ \\
\hline 6 & 50 & + & + & - & + & 10 & $7.0(0.8)$ \\
\hline 7 & 53 & + & + & - & + & 9 & $6.3(0.7)$ \\
\hline 8 & 54 & + & - & + & - & 36.4 & $7.4(0.9)$ \\
\hline 9 & 56 & + & - & + & - & 10 & $6.4(0.6)$ \\
\hline 10 & 45 & + & - & + & - & 22 & $8.0(0.8)$ \\
\hline 11 & 46 & + & - & + & - & 0 & $6.5(0.3)$ \\
\hline 12 & 44 & + & - & + & - & 22 & $5.6(0.5)$ \\
\hline 13 & 42 & + & - & - & + & 10 & $6.9(0.4)$ \\
\hline 14 & 37 & + & - & + & - & 18 & $6.3(0.7)$ \\
\hline 15 & 35 & + & - & - & + & 10 & $6.3(0.3)$ \\
\hline 16 & 34 & + & - & + & - & 11 & $6.3(0.8)$ \\
\hline 17 & 31 & + & - & - & + & 9 & $7.2(0.5)$ \\
\hline 18 & 27 & + & - & + & - & 17 & $7.2(0.6)$ \\
\hline 19 & 25 & + & - & + & - & 58 & $6.6(0.4)$ \\
\hline 20 & 22 & - & - & + & - & 0 & $5.4(0.2)$ \\
\hline 21 & 87 & + & - & + & - & 36.4 & $7.3(0.8)$ \\
\hline 22 & 80 & + & - & - & + & 10 & $7.4(0.5)$ \\
\hline $23^{*}$ & $90-128$ & + & - & + & - & 0 & $5.8(0.4)$ \\
\hline 24 & 57 & + & - & - & + & 10 & $6.4(0.6)$ \\
\hline 25 & 58 & + & - & + & - & 10 & $6.4(0.6)$ \\
\hline 26 & 59 & + & + & - & + & 10 & $6.4(0.8)$ \\
\hline 27 & 61.5 & + & - & + & - & 10 & $6.4(0.4)$ \\
\hline 28 & 29 & + & - & + & - & 9 & $7.2(0.5)$ \\
\hline 29 & 31.5 & + & - & + & - & 9 & $7.1(0.3)$ \\
\hline 30 & 32.3 & + & - & + & - & 9 & $7.2(0.6)$ \\
\hline 31 & 24 & + & + & - & + & 0 & $5.4(0.2)$ \\
\hline 32 & 23 & + & - & - & + & 0 & $5.2(0.5)$ \\
\hline 33 & 22.8 & + & - & - & + & 0 & $5.5(0.1)$ \\
\hline 34 & 22.6 & + & - & - & + & 0 & $5.6(0.4)$ \\
\hline 35 & 22 & + & - & + & - & 0 & $5.4(0.2)$ \\
\hline 36 & 20 & + & - & - & + & 0 & $5.0(0.1)$ \\
\hline 37 & 19 & + & - & - & + & 0 & $5.5(0.5)$ \\
\hline 38 & 18.5 & + & - & + & - & 0 & $5.4(0.6)$ \\
\hline 39 & 18 & + & + & + & - & 9 & $5.1(0.4)$ \\
\hline 40 & 38 & + & - & - & + & 9 & $6.4(0.4)$ \\
\hline Control (non-immunised) & $\ldots$ & $\ldots$ & $\ldots$ & $\ldots$ & $\ldots$ & 0 & $5.7(0.8)$ \\
\hline
\end{tabular}

${ }^{*}$ Complex of minor proteins.

Serological relationship of YPPS 2, 8, 19 and 21

To understand the immunological relationship between proteins 2, 8, 19 and 21, MAbs to each of them were allowed to react with antigen 1 and 2 dotted on to membranes. Antigen 1 was recognised by all the MAbs. Specific staining was very intense and equal in every case.

Antigen 2 was recognised by MAbs against YPPs 8, 19 and 21; the MAb against YPP 2 did not react with it. The specific staining was less intense with MAbs against YPP 8 and YPP 19 than with the MAb against YPP 21.

\section{Auto-agglutination}

Because auto-agglutination of yersiniae depends on the virulence plasmid and the active growth of bacteria at $37^{\circ} \mathrm{C}$ [3], inhibition of auto-agglutination by MAbs was studied. All the MAbs inhibited auto-agglutination of Y. pestis EV-76 cells cultivated at $37^{\circ} \mathrm{C}$. Y. pestis EV-76 cells suspended in $\mathrm{NaCl} 0.9 \%$ in the absence of MAbs auto-agglutinated (a control).

\section{Haemagglutination}

The lectin properties of YPPs 2, 8, 19 and 21 were studied by haemagglutination assays in the presence and absence of different sugars. Table 3 shows the specific inhibition of agglutination of antigens 1,2 and anti-Id-Abs to YPPs 2, 8, 19 and 21 with SRBC by Nacetylglucosamine. The same results were obtained when HRBC were used.

Antigen 2 demonstrated the same lectin specificity as described previously [28]. 


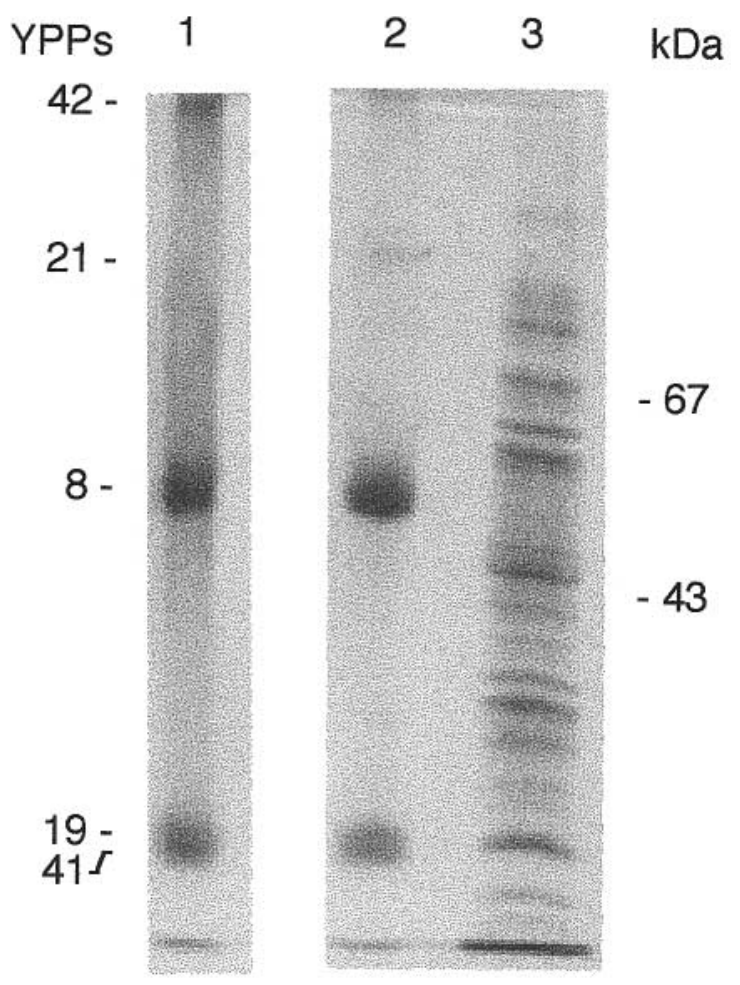

Fig 3. SDS-PAGE of affinity purified antigen 1 denatured in Laemmli solubilisation buffer without 2-mercaptoethanol (lane 1) or containing 2-mercaptoethamol (2) and $Y$. pestis EV-76 (grown on Hottinger agar at $28^{\circ} \mathrm{C}$ ) in the presence of 2-mercaptoethanol (3).

\section{Adjuvant activity of antigen 2}

The ELISA antibody titres in BALB/c mice after immunisation with $Y$. pseudotuberculosis II and V serovars and after combination with antigen 2 are presented in Fig. 4. The mean specific antibody titre in mice treated with $Y$. pseudotuberculosis II was 640, and with Y. pseudotuberculosis V was 1280. Combined immunisation with $Y$. pseudotuberculosis II and antigen 2 and $Y$. pseudotuberculosis $\mathrm{V}$ and antigen 2 led to a 7.81 -fold increase of specific antibody titres.

\section{Discussion}

In this study a novel method of $Y$. pestis cultivation in ACM-Sh and the most suitable culture medium devel- oped at this institute in combination with a delicate method of protein extraction was exploited for the isolation of pLCR products. The medium used has been shown to be optimal for the synthesis of pLCR products of $Y$. pestis EV-76, its isogenic variants and other virulent plague and pseudotuberculosis bacteria $[16,18,27]$. As a result, more pLCR-encoded products were isolated than have been described previously [1]. At present some 25 Yops, including a secretin, have been shown to compose the Ysc $[1,2,5-7,14]$. However, new LCR members can be potentially revealed, as 60 apparently intact open reading frames were described in pCD1 of $Y$. pestis KIM-5 [15]. The results of the present study support this finding. About 40 YPPs were found in $Y$. pestis KM-217 containing only pLCR, among which several were also identified in the $Y$. pestis KM-218 strain lacking plasmids.

A strong argument emphasising the merits of the method for $Y$. pestis cultivation is the fact that in the experiments with extracted YPPs, V antigen (YPP 14) and Yops 1-7 (YPP 1, 12, 13, 15, 19, 32, 39, respectively) and Yops $\mathrm{B}-\mathrm{E}, \mathrm{K}$ and $\mathrm{L}[7,14]$ were defined. The specificity and immunological relationship of YPPs to the relevant Yops were established by immunoblotting with absorbed anti-LCR antisera [16] (data not shown) confirming the high homology of highly conserved LCR plasmids and identity of most of their products in all three pathogenic yersiniae shown earlier. It was difficult to identify the remaining YPPs as Yops because many of them were of similar mass. For example, YopH could be 45-kDa YPP 10, 46-kDa YPP $11,53-\mathrm{kDa}$ YPP 7 or $54-\mathrm{kDa}$ YPP 8; and YopN could be $35-\mathrm{kDa}$ YPP 15 or $34-\mathrm{kDa}$ YPP 16 . Nevertheless, the YPPs preparation of $Y$. pestis KM-217 contained 25 known proteins and at least 10 potentially new members of the LCR family.

Most Yops are degraded in vitro by the pla protease [26], making study of these proteins in $Y$. pestis difficult. In some reports, degradation by pla protease is considered to be an in-vitro artifact [26, 29]. However, in the YPPs-EV-76 profile, several highly immunogenic YPPs like 2, 8, 19 and 21 were found. These proteins appeared to be resistant to pla protease. Most likely, Fib encoded by pPst serves as a possible native activator of protein precursors of pLCR-pro-

Table 3. Inhibition by sugars of haemagglutination of SRBC by antigens 1 and 2 and anti-Id-Abs against YPPs 2, 8, 19 and 21

\begin{tabular}{|c|c|c|c|c|c|c|c|c|}
\hline \multirow[b]{2}{*}{$\begin{array}{l}\text { Sugar } \\
(1 \mathrm{mg} / \mathrm{ml})\end{array}$} & \multicolumn{8}{|c|}{ Haemagglutination with } \\
\hline & Antigen 1 & Antigen $2^{*}$ & $\begin{array}{l}\text { Anti-Id-Ab } \\
\text { to YPP2 }\end{array}$ & $\begin{array}{l}\text { Anti-Id-Ab } \\
\text { to YPP8 }\end{array}$ & $\begin{array}{l}\text { Anti-Id-Ab } \\
\text { to YPP19 }\end{array}$ & $\begin{array}{l}\text { Anti-Id-Ab } \\
\text { to YPP21 }\end{array}$ & $\begin{array}{c}\text { Normal mouse } \\
\text { IgG }\end{array}$ & PBS \\
\hline Glucose & + & + & + & + & + & + & - & - \\
\hline Galactose & + & + & + & + & + & + & - & - \\
\hline N-Acetylglucosamine & - & - & - & - & - & - & - & - \\
\hline L-Fucose & + & + & + & + & + & + & - & - \\
\hline Sialic acid & + & + & + & + & + & + & - & - \\
\hline
\end{tabular}

*With permission of Dr A. A. Scherbakov [28] 


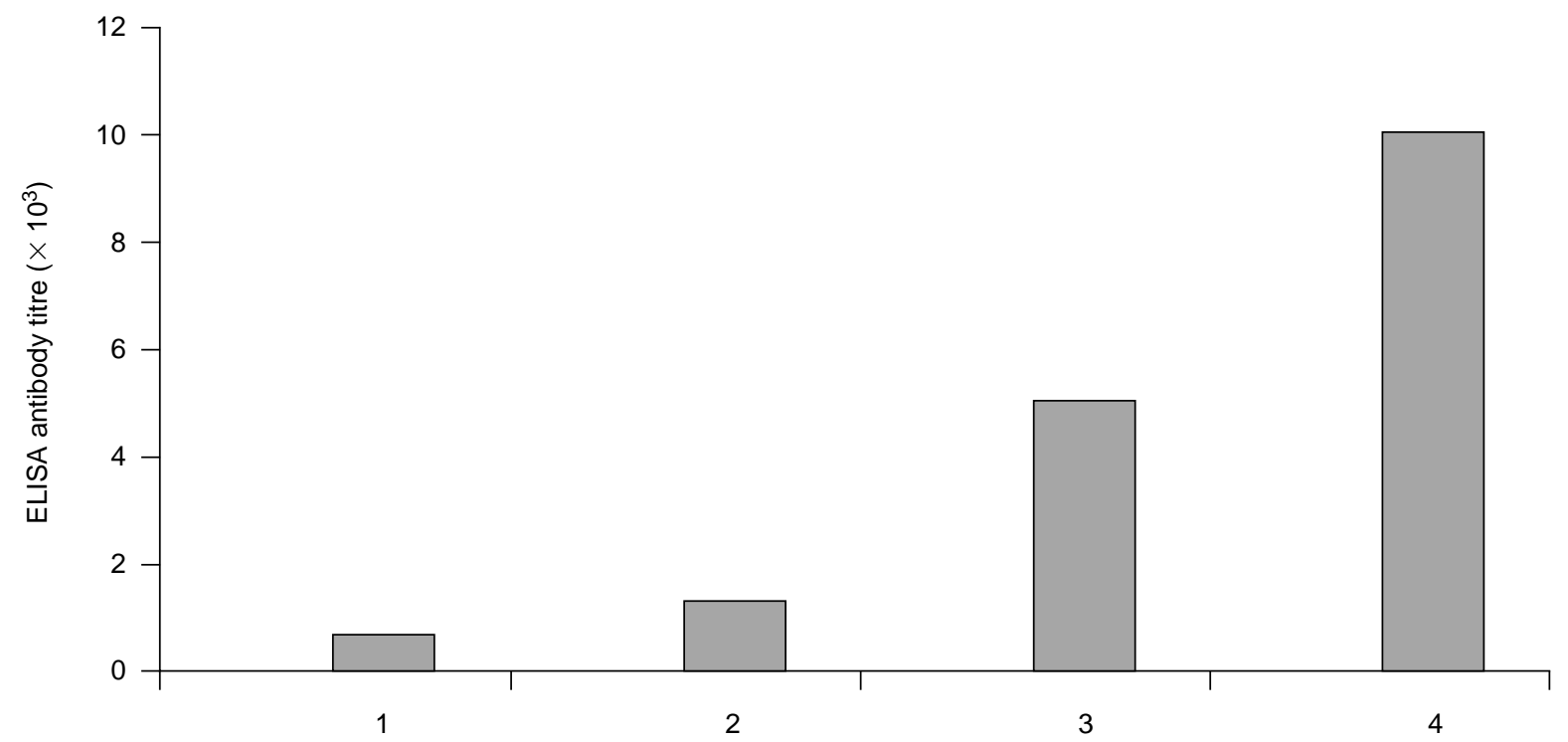

Fig 4. ELISA antibody titres in mice immunised with $Y$. pseudotuberculosis II (1), Y. pseudotuberculosis II mixed with antigen 2 (2), Y. pseudotuberculosis V (3) and Y. pseudotuberculosis V mixed with antigen 2 (4).

ducts, converting them into their active (mature) forms which are virulence factors for $Y$. pestis. Based on mass comparisons, YPP 19 was YopE, YPP 2 could be YopF, YPP 8 could be YopH and YPP 21 could be YopO. On the other hand, as YopF was identified as a $74-\mathrm{kDa}$ YPP 1 in immunoblotting with anti-LCR antisera, 72kDa YPP 2 could possibly be a new member of the LCR system.

Studies of $Y$. pestis strains from various natural plague foci of the Confederation of Independent States and other countries showed that $71 \%$ of them carried the three 'canonical' plasmids: pPst, pLCR (pCad), pFra [30]. Thus, the presence of both pPst and PLCR in $Y$. pestis is not extraordinary and the interaction of the products of these plasmids does take place.

Protective antibodies are able to neutralise only those antigens that are surface-located and available for interaction [31]. Maximal expression and secretion of Yops in vitro occurs at $37^{\circ} \mathrm{C}$ in a medium lacking $\mathrm{Ca}^{2+}$ - conditions imitating the intracellular environment in mammals $[5,32]$. This is supported by $Y$. pestis survival within the macrophages - their target cells $[13,33]$. Being located intracellularly, Yops become unavailable for neutralisation by the relevant antibodies. In the presence of $\mathrm{Ca}^{2+}$, virulence plasmidencoded operons are transcriptionally down-regulated $[7,8]$ and Yop secretion is blocked $[8,9,29]$. However, Bolin et al. have reported that small amounts of Yops were detectable in the $Y$. pestis outer membrane at $37^{\circ} \mathrm{C}$ in the presence of $2.5 \mathrm{~mm}$ calcium [34]. Furthermore, the expression of Yops of 51-52 and 25 $\mathrm{kDa}$ (referred to as YPPs 8 and 19, respectively, in this paper) is more strongly influenced by growth temperature than by calcium concentration [32].

Moreover, YopE (also called YopN [35] and named
YPP 19 in this study), is known to play a leading role in $\mathrm{Ca}^{2+}$-sensing $[8,35,36]$. This function of YopE (YPP 19) can be realised only if the $\mathrm{Ca}^{2+}$-sensing receptor is located on the microbial cell surface before phagocytosis and, thus, is capable of monitoring the calcium concentration in the surrounding medium. Some data indicated that YPP 19 was not only secreted (mature form) by $Y$. pestis, but was also present as a precursor on the cell surface of the bacterium. YPP 19 was isolated from both OMPs (antigen 2) and YPPs (antigen 1) by affinity chromatography with MAb to YPP 19. The preparations were marked by a certain variability. Antigen 2 was a $22-\mathrm{kDa}$ protein, whose native conformation appeared to be more complex than its denatured form and consisted of two subunits with a disulphide linkage. Antigen 1 had a more complex quaternary structure. It consisted of five subunits among which subunit N 4 (YPP 21) was linked to the others by disulphide bonds. This suggests that YPP 19 (YopE) exists in two forms: a precursor (antigen 2) and an active (mature) form (antigen 1). Being a surface structure of $Y$. pestis, YPP 19 can be neutralised by the relevant antibodies. This possibly induced a highly protective immune response in mice immunised with YPP 19 and its subunits, as well as guinea-pigs immunised with a $22-\mathrm{kDa}$ protein [28]. In the preliminary protective experiments, immunisation with YPPs provided complete protection of guinea-pigs against virulent $Y$. pestis strain 231 even after a single injection [27]. This phenomenon was explained by the presence of $\mathrm{V}$ antigen in the YPPs preparation used for immunisation, as $\mathrm{V}$ antigen plays a dominant role in protection [20,37]. However, YPP 19 appeared to be five or six times more protective than YPP 14 identified by the present study as $\mathrm{V}$ antigen. This makes YPP 19 a potential vaccine candidate.

More evidence for the location of YPP 19 and its 
subunits on the surface of $Y$. pestis cell wall was the ability of the relevant MAbs to react with whole cells of $Y$. pestis KM-217 and to a lesser extent with EV-76, as shown by ELISA and IIFT.

A surprising finding in this study was that antigens 1 and 2 and their subunits possessed a number of common activities, i.e., (i) highly immunogenic properties (induction of protective immunity); (ii) marked antigenic properties (induction of specific antibodies in high titres); (iii) adhesive activity; (iv) oligosaccharidebinding properties of a lectin with specificity for $\mathrm{N}$ acetylglucosamine; (v) serological relationship of all the peptides to each other; (vi) participation of these proteins in the auto-agglutination of $Y$. pestis; and (vii) adjuvant properties. Interestingly, YopE (YPP 19) is a cytotoxin $[38,39]$ and strains producing YopE possess high mitogenic activity [40]. It is known that agglutination, cytotoxic, mitogenic and carbohydratebinding properties are essential properties of lectins. The results of the present study suggest that YPP 19 fits this pattern. Being a lectin, YPP 19 probably has an immunoglobulin-like structure with $\beta$-sheet conformation and that is why it is capable of specific proteinprotein interactions with its specific yop chaperone termed SycE [41] (also called YcrA [42]). This protein, located on the cell surface of $Y$. pestis (antigen 2), is probably involved in the $\mathrm{N}$-acetylglucosamine-specific adherence of the bacterium to eukaryotic cells, which can result in Ysc activation and Yop targeting that is associated with the $\mathrm{Ca}^{2+}$-sensing function of YopE $[8,35,36]$. The presence of an $\mathrm{N}$-acetylglucosamine receptor on the surface of the macrophage [43] makes this hypothesis feasible. Otherwise, the receptor for antigen 1 may be the relevant oligosaccharide located intracellularly.

Lysozyme also has oligosaccharide-binding properties with specificity for $\mathrm{N}$-acetylglucosamine [44]. The same lectin specificity of YPP 19 shown in this study strongly indicates that both substances are directed to the same receptor, which may be located on the external surface of $Y$. pestis. In this case, YPP 19 competes with lysozyme for carbohydrate epitopes of $Y$. pestis, coating them with the protein (YPP 19, antigen 1). Thus, the bacterium becomes resistant to phagocytosis, as proteins are resistant to lysozyme [44]. On the other hand, being secreted, YPP 19 can possibly neutralise lysozyme activity in the phagolysosome space and prevent phagocytosis. In each case, a phagocyte loses its ability to present peptide fragments of $Y$. pestis to the host immune system. It does not react as a professional antigen-presenting cell and as a result an adaptive immune response cannot be induced. This possible explanation for unstable immunity against plague seems very likely, because there is only one enzyme in phagolysosomes with specificity for $\mathrm{N}$-acetylglucosamine. As a result, the cell wall remains intact and no degradation of the microbial cell occurs.
These data explain the lower virulence and avirulence of $Y$. pestis strains lacking yopE [7,38]. A high level of protection produced in mice immunised with YPP 19 provides more evidence of the role of this protein in phagocytosis. This suggests that YopE is the major factor in plague pathogenesis. $Y$. pestis probably possesses a set of YPPs (Yops) with a similar biological function that may be represented by YPP 2, 8 and 21, YPP 19 subunits and other immunologically related proteins which cross-reacted with antibodies to YPP 19, for instance, proteins of 22, 36, $47 \mathrm{kDa}$ described by Chalvignac et al. [17]. This conclusion is based on the observation that crossreacting YPPs 2, 8, 19 and 21 demonstrated full coincidence of other properties.

The existence in $Y$. pestis of many proteins with similar functions indicates that they play the key role in resistance of $Y$. pestis to phagocytosis.

We thank Dr I. A. Dyatlov for the Y. pestis KM-217 YPPs preparation and for cultivation of $Y$. pestis strains in ACM-Sh, Dr A. A. Scherbakov for providing Y. pestis EV-76 OMPs, Dr M. V. Sumaroka for help in affinity purification of the antigens, Mrs Ye. V. Mitina for excellent technical assistance and N. Ye Teryoshkina for help in preparing the manuscript and continuous encouragement.

\section{References}

1. Cornelis GR, Boland A, Boyd AP et al. The virulence plasmid of Yersinia, an antihost genomee. Microbiol Mol Biol Rev 1998; 62: 1315-1352.

2. Portnoy DA, Wolf-Watz H, Bolin I, Beeder AB, Falkow S. Characterization of common virulence plasmids in Yersinia species and their role in the expression of outer membrane proteins. Infect Immun 1984; 43: 108-114.

3. Laird WJ, Cavanaugh DC. Correlation of autoagglutination and virulence of yersiniae. J Clin Microbiol 1980; 11: 430-432.

4. Pai $\mathrm{CH}$, DeStephano L. Serum resistance associated with virulence in Yersinia enterocolitica. Infect Immun 1982; 35: $605-611$.

5. Straley SC, Brubaker RR. Cytoplasmic and membrane proteins of Yersinia cultivated under conditions simulating mammalian intracellular environment. Proc Natl Acad Sci USA 1981; 78: 1224-1228.

6. Bölin I, Norlander L, Wolf-Watz H. Temperature-inducible outer membrane protein of Yersinia pseudotuberculosis and Yersinia enterocolitica is associated with the virulence plasmid. Infect Immun 1982; 37: 506-512.

7. Straley SC, Bowmer WS. Virulence genes regulated at the transcriptional level by $\mathrm{Ca}^{2+}$ in Yersinia pestis include structural genes for outer membrane proteins. Infect Immun 1986; 51: 445-454.

8. Straley SC, Plano GV, Skrzypek E, Haddix PL, Fields KA. Regulation by $\mathrm{ca}^{2+}$ in the Yersinia low- $\mathrm{Ca}^{2+}$ response. $\mathrm{Mol}$ Microbiol 1993; 8: 1005-1010.

9. Cornelis GR, Wolf-Watz H. The Yersinia. Yop virulon: a bacterial system for subverting eukaryotic cells. Mol Microbiol 1997; 23: 861-867.

10. Straley SC, Perry RD. Environmental modulation of gene expression and pathogenesis in Yersinia. Trends Microbiol 1995; 3: 310-317.

11. Iriate M, Sory M-P, Boland A et al. TyeA, a protein involved in control of Yop release and in translocation of Yersinia Yop effectors. EMBO J 1998; 17: 1907-1918.

12. Nilles ML, Field KA, Straley SC. The V antigen of Yersinia pestis regulates Yop vectorial targeting as well as Yop secretion through effects on YopB and LcrG. J Bacteriol 1998; 180: $3410-3420$.

13. Straley SC, Harmon PA. Yersinia pestis grows within 
phagolysosomes in mouse peritoneal macrophages. Infect Immun 1984; 45: 655-659.

14. Bölin I, Portnoy DA, Wolf-Watz H. Expression of the temperature-inducible outer membrane proteins of yersiniae. Infect Immun 1985; 48: 234-240.

15. Perry RD, Straley SC, Fetherston JD, Rose DJ, Gregor J, Blattner FR. DNA sequencing and analysis of the low-Ca ${ }^{2+}$. response plasmid pCD1 of Yersinia pestis KIM5. Infect Immun 1998; 66: 4611-4623.

16. Vidiaeva NA, Kutyrev VV, Protsenko OA, Oleinikov PN, Anisimov P1. [Expression of Yersinia pestis antigens coded by the $\mathrm{Ca}^{2+}$-dependence plasmid]. Mol Gen Microbiol Virusol 1990; 6: 17-21.

17. Chalvignac M-A, Carniel E, Tram C, Joseph - Francois A, Mollaret HH. In vitro expression of a 22-kilodalton Yersinia pestis polypeptide immunologically related to the 25-kilodalton plasmid-encoded protein of the three pathogenic Yersinia species. Infect Immun 1988; 56: 2576-2580.

18. Korobova OV, Taranenko TM, Korobov BI. Studying of influence of cultivation conditions upon $Y$. pestis EV-76 V and $\mathrm{W}$ antigens biosynthesis. In: Problems of plague and cholera specific prophylaxis. Russia State Research Antiplague Institute "Microbe", Saratov, Russia. 1985: 10-14.

19. Laemmli UK. Cleavage of structural proteins during the assembly of the head of bacteriophage T4. Nature 1970; 227: $680-685$.

20. Osborn MJ, Gander JE, Parisi E, Carson J. Mechanism of assembly of the outer membrane of Salmonella typhimurium. Isolation and characterization of cytoplasmic and outer membrane. J Biol Chem 1972; 247: 3962-3972.

21. Ouchterlony Ö. Antigen-antibody reactions in gels. IV. Types of reactions in coordinated systems of diffusion. Acta Pathol Microbiol Scand 1953; 32: 231-240.

22. Anderson GW, Leary SEC, Williamson ED et al. Recombinant $\mathrm{V}$ antigen protects mice against pneumonic and bubonic plague caused by F1-capsule-positive and negative strains of Yersinia pestis. Infect Immun 1996; 64: 4580-4585.

23. Ishikawa E, Imagawa $\mathrm{M}$, Hashida $\mathrm{S}$ et al. Enzyme labeling of antibodies and their fragments for enzyme immunoassay immunohistochemical studies. $J$ Immunoassay 1983; 4 209-327.

24. Slifkin M, Doyle RJ. Lectins and their application in clinical microbiology. Clin Microbiol Rev 1990; 3: 197-218.

25. Galfre G, Howe SC, Milstein C, Butcher GW, Howard JC. Antibodies to major histocompatibility antigens produced by hybrid cell lines. Nature 1977; 266: 550-552.

26. Sodeinde OA, Sample AK, Brubaker RR, Goguen JD Plasminogen activator/coagulase gene of Yersinia pestis is responsible for degradation of plasmid-encoded outer membrane proteins. Infect Immun 1988; 56: 2749-2752.

27. Dyatlov IA, Filippov AF. Protective activity of watersoluble proteins encoded by Yersinia pestis calcium-dependence plasmid. In: Immunology and specific prophylaxis of particularly dangerous infections. Russia State Research Antiplague Institute "Microbe". Saratov, Russia. 1993: 10-11.

28. Scherbakov AA. Membrane proteins of Yersinia pestis (theoretical and applied aspects). DSc Thesis. Russia State Antiplague Reseach Institute "Microbe", Saratov, Russia. 1991.

29. Fowler JM, Brubaker RR. Physiological basis of the low calcium response in Yersinia pestis. Infect Immun. 1994; 62: 5234-5241.

30. Filippov AA, Solodovnikov NS, Kookleva LM, Protsenko OA. Plasmid content in Yersinia pestis strains of different origin. FEMS Microbiol Lett 1990; 67: 45-48.

31. Burrows TW. Genetics of virulence in bacteria. $\mathrm{Br}$ Med Bull 1962; 18: 69-73.

32. Skurnik M. Expression of antigens encoded by the virulence plasmid of Yersinia enterocolitica under different growth conditions. Infect Immun 1985; 47: 183-190.

33. Kookleva LM. Phagocytosis of Yersinia pestis strains differing in virulence and antigenic composition by peritoneal and alveolar macrophages. $\mathrm{PhD}$ Thesis. Russia State Antiplague Reseach Institute "Microbe", Saratov, Russia. 1989.

34. Bölin I, Forsberg A, Norlander L, Skurnik M, Wolf-Watz H. Identification and mapping of the temperature-inducible, plasmid-encoded proteins of Yersinia spp. Infect Immun 1988; 56: 343-348.

35. Forsberg A, Viitanen AM, Skurnik M, Wolf-Watz H. The surface-located YopN protein is involved in calcium signal transduction in Yersinia pseudotuberculosis. Mol Microbiol 1991; 5: 977-978.

36. Rimpiläinen M, Forsberg A, Wolf-Watz H. A novel protein, Lcrq, involved in the low-calcium response of Yersinia pseudotuberculosis shows extensive homology to YopH. $J$ Bacteriol 1992; 174: 3355-3363.

37. Leary SEC, Williamson ED, Griffin KF, Russell P, Eley SM, Titball RW. Active immunization with recombinant $\mathrm{V}$ antigen from Yersinia pestis protects mice against plague. Infect Immun 1995; 63: 2854-2858.

38. Rosqvist R, Forsberg A, Rimpilainen M, Bergmann T, WolfWatz H. The cytotoxic protein YopE of Yersinia obstructs the primary host defence. Mol Microbiol 1990; 4: 657-667.

39. Rosqvist R, Magnusson K-E, Wolf-Watz H. Target cell contact triggers expression and polarized transfer of Yersinia YopE cytotoxin into mammalian cells. EMBO J 1994; 13: 964-972.

40. Emelyanova NV. Influence of Yersinia pestis antigens and strains differing in expression of immunogenic and virulence determinants upon the level of lymphocyte blast transformation and activity of interleukins ( 1 and 2 ) at development immunity to plague. PhD Thesis. Russia State Antiplague Research Institute "Microbe", Saratov, Russia. 1992

41. Wattiau P, Cornelis GR. SycE, a chaperone-like protein of Yersinia enterocolitica involved in the secretion of YopE. Mol Microbiol 1993; 8: 121-131.

42. Frithz-Lindsten E, Rosqvist R, Johansson L, Forsberg A. The chaperone-like protein YcrA of Yersinia pseudotuberculosis stabilizes YopE in the cytoplasm but is dispensable for targeting to the secretion loci. Mol Microbiol 1995; 16: 635-647.

43. Shevach E. Macrophages and other helper cells. In: Paul WE (ed) Immunology. Mir, Moscow, USSR. 1990: 144. [Translated from Paul WE (ed) Fundamental immunology. National Institutes of Health, Bethesda, MD, Raven Press, New York 1984.]

44. Metzler DE (ed). Biochemistry: The chemical reactions of living cells. Mir, Moscow, USSR. 1980: 98-99. [Translated from Metzler DE. Biochemistry: The chemical reactions of living cells. New York, Academic Press. 1977]. 